\title{
Originals
}

\section{Diabetes mellitus in Macaca mulatta monkeys is characterised by islet amyloidosis and reduction in beta-cell population}

\author{
E.J.P. de Koning ${ }^{1}$, N.L.Bodkin ${ }^{2}$, B.C.Hansen ${ }^{2}$ and A.Clark ${ }^{1}$ \\ ${ }^{1}$ Diabetes Research Laboratories, Radcliffe Infirmary, Oxford, UK \\ ${ }^{2}$ Department of Physiology, Obesity and Diabetes Research Center, University of Maryland Medical School, Baltimore, Maryland, USA
}

\begin{abstract}
Summary. Diabetes mellitus in Macaca mulatta rhesus monkeys is preceded by phases of obesity and hyperinsulinaemia and is similar to Type 2 (non-insulin-dependent) diabetes mellitus in man. To relate the progression of the disease to quantitative changes in islet morphology, post-mortem pancreatic tissue from 26 monkeys was examined. Four groups of animals were studied: group I - young, lean and normal $(n=3)$; group II - older ( $>10$ years), lean and obese, normoglycaemic $(n=9)$; group III - normoglycaemic and hyperinsulinaemic $(n=6)$; group IV - diabetic $(n=8)$. Areas of islet amyloid, beta cells and islets were measured on stained histological sections. Islet size was larger in animals from groups III $(p<0.01)$ and IV $(p<0.0001)$ compared to groups $I$ and II. The mean beta-cell area per islet in $\mu \mathrm{m}^{2}$ was increased in group III $(p<0.05)$ and reduced in group IV $(p<0.001)$ compared to groups I and II. Mean beta-cell area per islet correlated with fasting plasma insulin $(r=0.76$,
\end{abstract}

$p<0.001$ ) suggesting that hyper- and hypoinsulinaemia are related to the beta-cell population. Amyloid was absent in group I but small deposits were present in three of nine (group II) and in four of six (group III) animals, occupying between $0.03-45 \%$ of the islet space. Amyloid was present in eight of eight diabetic animals (group IV) occupying between $37-81 \%$ of the islet area. Every islet was affected in seven of eight diabetic monkeys. There was no correlation of degree of amyloidosis with age, body weight, body fat proportion or fasting insulin. Islet amyloid appears to precede the development of overt diabetes in Macaca mulatta and is likely to be a factor in the destruction of islet cells and onset of hyperglycaemia.

Key words: Type 2 (non-insulin-dependent) diabetes mellitus, Macaca mulatta, islet of Langerhans - pathology, amyloid, islet amyloid polypeptide, beta cells, obesity.
Amyloid deposits in islets of Langerhans are associated with Type 2 (non-insulin-dependent) diabetes mellitus in man [1-3] but the role of amyloid formation in the pathogenesis of the disease is unclear. Amyloid may be a primary factor in the pathophysiology of Type 2 diabetes [4] or may arise secondarily to beta-cell dysfunction. Progressive amyloid formation contributes to increased severity of the disease in man [5].

The major protein constituent of islet amyloid is a 37 amino acid peptide, islet amyloid polypeptide (IAPP) [6, 7], which is co-localized with insulin in secretory granules of the beta cell $[8,9]$ and co-secreted following a glucose $[10,11]$ or amino acid stimulus [12]. Although IAPP is present in all species examined so far [13], diabetes-associated islet amyloid has been found only in man, monkeys and cats [14]. This restriction may be related to a combination of species-specific variations in the sequence of IAPP and, as yet unknown, causative factors in the conversion of soluble IAPP into insoluble fibrils [15]. The IAPP sequence in Macaca mulatta has not been determined but in another macaque species, Macaca nemestrina, the sequence differs from human IAPP in only three amino acids [16].

The development of diabetes in Macaca mulatta [17, $18]$ is associated with obesity and insulin resistance and it appears to be very similar to Type 2 diabetes in man. This is unlike development of diabetes in Macaca nigra which is characterised by lack of obesity and hypoinsulinaemia. $[19,20]$. In this latter animal model, diabetes is associated with amyloid deposition [21].

In Macaca mulatta the age of onset of diabetes ranges from 10 to 29 years and most commonly commences between 15 and 25 years ("middle age" for monkeys). A series of phases have been identified in the progression of the disease [18]; animals, older than 7 years with free access to food often become obese and some obese monkeys develop insulin resistance and increased basal and stimulated insulin secretion. This phase is followed by glucose intolerance and impaired beta-cell responses with basal insulin levels declining toward or below normal. Hyper- 
Table 1. Physiological data

\begin{tabular}{|c|c|c|c|c|c|c|c|}
\hline Group & $\begin{array}{l}\text { Mon- } \\
\text { key }\end{array}$ & $\begin{array}{l}\text { Age } \\
\text { (years) }\end{array}$ & $\begin{array}{l}\text { Weight } \\
\text { (kg) }\end{array}$ & $\begin{array}{l}\text { Body } \\
\text { fat } \\
(\%)\end{array}$ & $\begin{array}{l}\text { Pan- } \\
\text { creas } \\
\text { (g) }\end{array}$ & $\begin{array}{l}\text { FPG } \\
(\mathrm{mmol} / \mathrm{l})\end{array}$ & $\begin{array}{l}\text { IRI } \\
(\mathrm{pmol} / \mathrm{l})\end{array}$ \\
\hline \multirow[t]{3}{*}{ I } & $\mathrm{A}$ & 2.1 & 2.6 & - & 5.8 & 2.6 & 201 \\
\hline & B & 2.2 & 2.7 & - & 6.5 & 2.7 & 187 \\
\hline & $\mathrm{Z}$ & 5.4 & 7.4 & 5.0 & 1.3 & 3.8 & 431 \\
\hline \multirow[t]{9}{*}{ II } & $\mathrm{C}$ & 17.5 & 9.8 & - & - & 3.6 & 215 \\
\hline & $\mathrm{G}$ & 21.3 & 10.1 & - & - & 3.3 & 194 \\
\hline & $\mathrm{V}$ & 13.0 & 9.8 & - & - & 3.1 & 115 \\
\hline & $\mathrm{T}$ & 13.2 & 10.6 & 21.9 & 11.4 & 3.8 & 345 \\
\hline & $\mathrm{P}$ & 29.8 & 7.6 & 16.3 & - & 4.4 & 101 \\
\hline & $\mathrm{L}$ & 14.5 & 15.5 & 34.0 & 9.4 & 3.0 & 338 \\
\hline & $\mathrm{S}$ & 15.7 & 15.1 & 35.8 & 12.2 & 3.6 & 273 \\
\hline & $E$ & 12.0 & 11.8 & 21.5 & 16.5 & 3.6 & 416 \\
\hline & $\mathrm{Q}$ & 29.3 & 7.8 & 39.8 & 7.6 & 3.4 & 618 \\
\hline \multirow[t]{6}{*}{ III } & M & 18.6 & 13.2 & 31.0 & 18.0 & 3.4 & 1034 \\
\hline & $\mathrm{H}$ & 19.5 & 22.9 & 39.5 & 14.6 & 3.6 & 1206 \\
\hline & $\mathrm{K}$ & 20.3 & 12.0 & 28.9 & 12.4 & 4.4 & 1479 \\
\hline & $\mathrm{J}$ & 22.8 & 17.1 & 41.7 & 14.5 & 6.4 & 2230 \\
\hline & $\mathrm{Y}$ & 18.0 & 10.8 & - & 15.4 & 3.9 & 1213 \\
\hline & $\mathrm{O}$ & 14.0 & 10.3 & - & 8.9 & 6.6 & 847 \\
\hline \multirow[t]{8}{*}{ IV } & I & 24.2 & 11.3 & 30.5 & 8.0 & 8.4 & 136 \\
\hline & $\mathrm{F}$ & 24.4 & 13.9 & 27.7 & 18.5 & 11.0 & 136 \\
\hline & W & 20.7 & 10.3 & 17.8 & 7.8 & 10.2 & 228 \\
\hline & $\mathrm{D}$ & 24.3 & 12.2 & 29.3 & - & 14.9 & 345 \\
\hline & $\mathrm{N}$ & 21.6 & 14.3 & 11.1 & 21.9 & 15.2 & 187 \\
\hline & $\mathrm{X}$ & 13.9 & 7.7 & 16.7 & 9.5 & 23.9 & 151 \\
\hline & $\mathrm{U}$ & 25.9 & 9.8 & 46.5 & 10.2 & 9.1 & 65 \\
\hline & $\mathrm{R}$ & 26.8 & 13.1 & 37.4 & 8.9 & 15.9 & 172 \\
\hline
\end{tabular}

$\mathrm{I}=$ lean, normoglycaemic, normoinsulinaemic monkeys, less than 10 years old $(n=3)$. II = lean and obese, normoglycaemic, normoinsulinaemic monkeys, more than 10 years old $(n=9)$. III $=$ normoglycaemic, hyperinsulinaemic monkeys (fasting immunoreactive insulin (IRI) $>700 \mathrm{pmol} / \mathrm{l})(n=6)$. IV = diabetic monkeys (fasting plasma glucose $(\mathrm{FPG})>7.8 \mathrm{mmol} / \mathrm{l})(n=8)$

glycaemia (fasting plasma glucose (FPG) $>7.8 \mathrm{mmol} / \mathrm{l}$ ) develops in association with declining pancreatic islet function. In the later phases, insulin-mediated glucose uptake during hyperinsulinaemic euglycaemic clamps is decreased. In addition, overtly diabetic monkeys develop complications similar to those seen in humans including neuropathy and dyslipidaemia. In the present study the relationships between amyloid deposition, beta-cell population, islet size, endocrine density and physiological data were examined in a cross section of lean, obese, hyperinsulinaemic and diabetic animals.

\section{Materials and methods}

\section{Physiological data}

Twenty-six Macaca mulatta monkeys were selected for this study. Fasting plasma immunoreactive insulin (IRI) and glucose concentrations were obtained at regular intervals together with measurements of body weight and proportion of body fat [18]. The last measurements for these parameters obtained within 2 months 'pre-mortem' are shown in Table 1. Monkeys were assigned to four groups according to their physiological status and age. Group I comprised lean, normoglycaemic and normoinsulinaemic monkeys less than 10 years of age. Group II comprised lean and obese, normoglycaemic, normoinsulinaemic monkeys older than 10 years of age. Group III comprised obese, hyperinsulinaemic (IRI $>700 \mathrm{pmol} / \mathrm{l}$ ), normoglycaemic animals. Diabetic monkeys were included in group $\mathrm{IV}$, with hyperglycaemia (FPG $>7.8 \mathrm{mmol} / \mathrm{l}$ ) and low or normal concentrations of fasting plasma insulin.

\section{Tissue preparation and immunostaining}

Anaesthetised animals were killed and the pancreas was removed, trimmed of surplus fat and weighed (Table 1). Specimens from the body and tail region (regions VI and VIII [22]) were taken and fixed in $10 \%$ formaldehyde in $0.9 \%$ sodium chloride. These tissue samples were processed for wax embedding. Histological sections were cut from each block and stained using the indirect peroxidase technique. Beta cells were identified by use of antisera to insulin (Miles Scientific, Bucks., Slough, UK), diluted 1: 1000, and peroxidase-conjugated anti-guinea pig antiserum (Miles Scientific). Amyloid was stained with Congo red and identified by use of a rabbit polyclonal antiserum to synthetic $\mathrm{IAPP}_{19-37}$, diluted 1: 1000, and a peroxidase conjugated anti-rabbit antiserum (Dako Ltd, High Wycombe, UK). Specificity of the insulin and IAPP antisera was confirmed by loss of immunoreactivity after preabsorption of the antisera with human insulin $(10 \mu \mathrm{g} / \mathrm{ml})$ and human $\operatorname{IAPP}_{1-37}(10 \mu \mathrm{g} / \mathrm{ml})$, respectively. As the IAPP fragment included the sequence $27-37$ which is similar to that found in calcitonin gene related peptide (CGRP), preabsorption with $\mathrm{CGRP}_{27-37}$ was performed. Immunoreactivity persisted thus excluding cross reactivity with this fragment of CGRP.

\section{Morphometry}

The stained slides were examined by quantitative morphometry with the investigator (EJPdK) unaware of the physiological status of the monkeys. Morphometry was performed using a manual optical picture image analyser (Model MOP-01, Kontron, Messergeraete, FRG) on a projected image of the histological section at a magnification of $630 \times$. The projected image was analysed in a rectangular field which corresponded to $11.5 \times 10^{3} \mu \mathrm{m}^{2}$ of the histological section. The entire section was examined in sequential fields and the size of the tissue area was determined from the number of fields; non-acinar tissue such as ducts, vascular bundles and adipose depositions were not included as part of the tissue area. All islets were measured on slides immunolabelled for insulin and IAPP. The boundary of the islet area (ISL) was identified adjacent to surrounding exocrine tissue and capillaries. Other measurements included islet beta-cell area (B), on the slides immunolabelled for insulin, and islet amyloid area (AM) on the slides immunolabelled for IAPP. A clear distinction could be made between amyloid deposits and intracellular IAPP-immunoreactivity since staining for IAPP with this antiserum in beta cells was low or absent in all monkeys and round nuclei or cellular outlines were absent from amyloid deposits. Only islet sections with an area greater than $100 \mu \mathrm{m}^{2}$ were included in the study, thus excluding single beta cells located outside islets and small groups of beta cells often found near capillaries.

The sum of islet areas ( $\Sigma$ ISL), beta-cell areas $(\Sigma \mathrm{B})$ and amyloid areas $(\Sigma \mathrm{AM})$ were determined to calculate the mean proportion of islet beta-cell area (B\%) and islet amyloid area (AM\%), respectively.

Reproducibility of the measurements was estimated in five specimens with a coefficient of variation of less than $10 \%$. The mean betacell area per islet and amyloid area per islet, expressed in $\mu \mathrm{m}^{2}$, were calculated through division of $\Sigma \mathrm{B}$ and $\Sigma \mathrm{AM}$, respectively, by the number of islets. The islet area proportion (ISL\%) of the tissue area was determined from $\Sigma$ ISL and tissue area for each specimen.

\section{Statistical analysis}

Data are presented as geometric mean or median and range. Islet area, beta-cell area and amyloid area measurements were logarithmically transformed since the distributions of these data were markedly skewed. This enabled comparison of data between individual monkeys and between different groups of animals. Animals in 
a

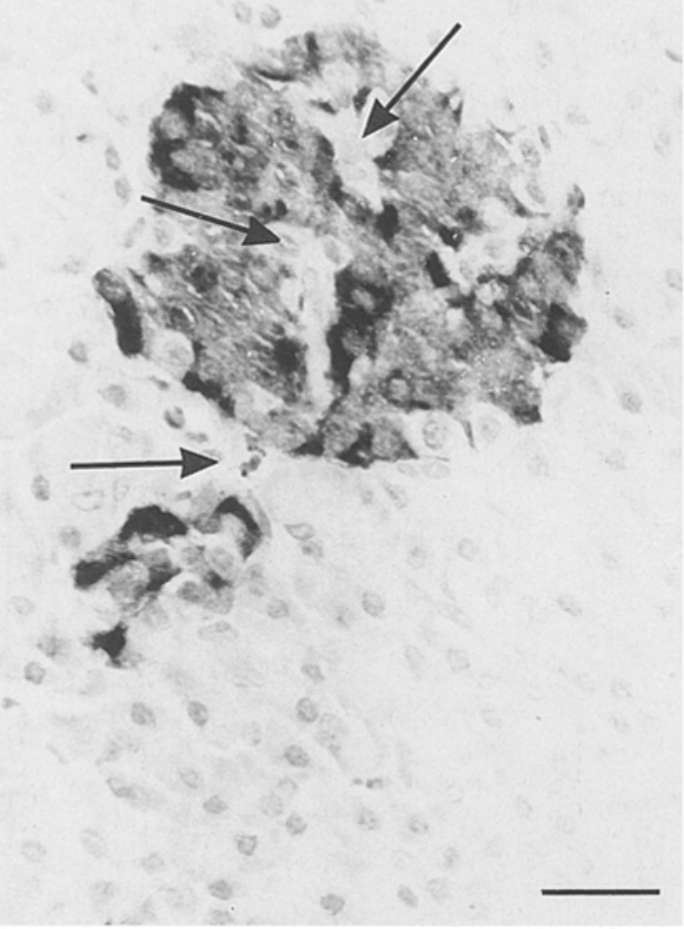

ins

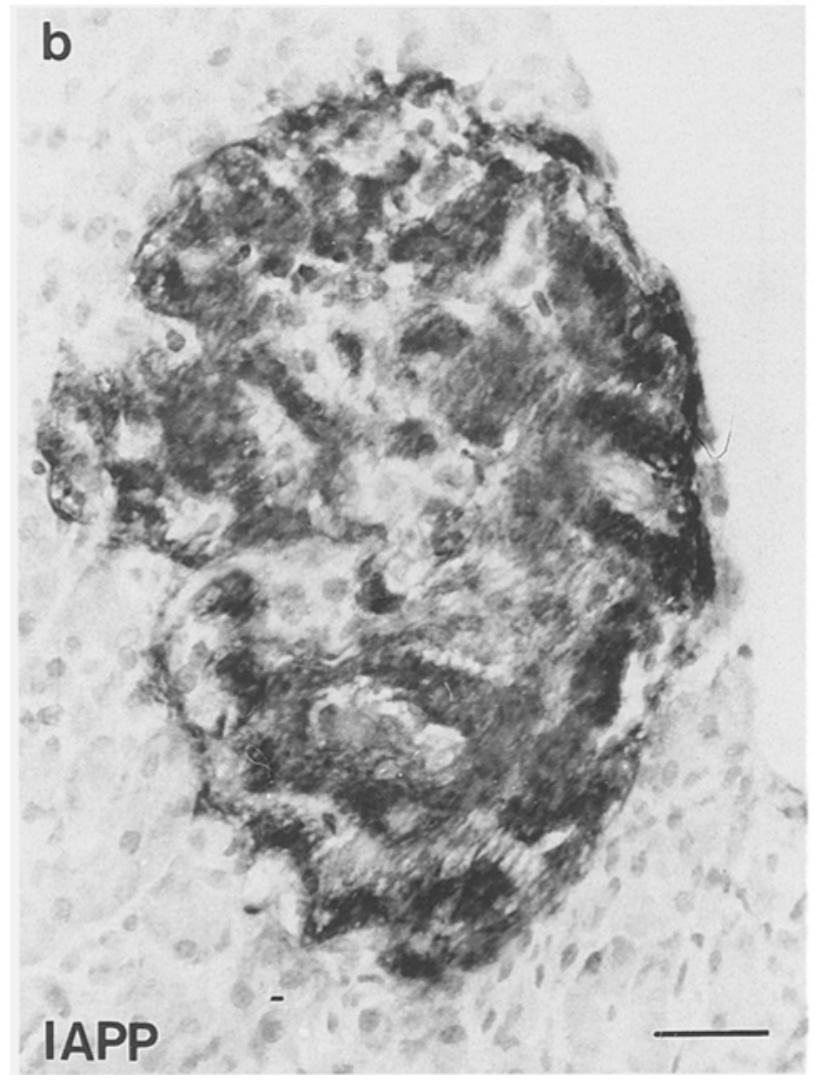

Fig.1 a-d. Immunoperoxidase labelled pancreatic islets. (a) Immunoreactivity for insulin in a non-diabetic animal (monkey $Z$ ). The beta cells occupy a large proportion of the islet. Unstained cells (arrows) line a capillary. This irregularly shaped islet is typical of primates. (b and c) Islet from a diabetic monkey (monkey W). Immunoreactivity for insulin (c) is restricted to small clusters of cells
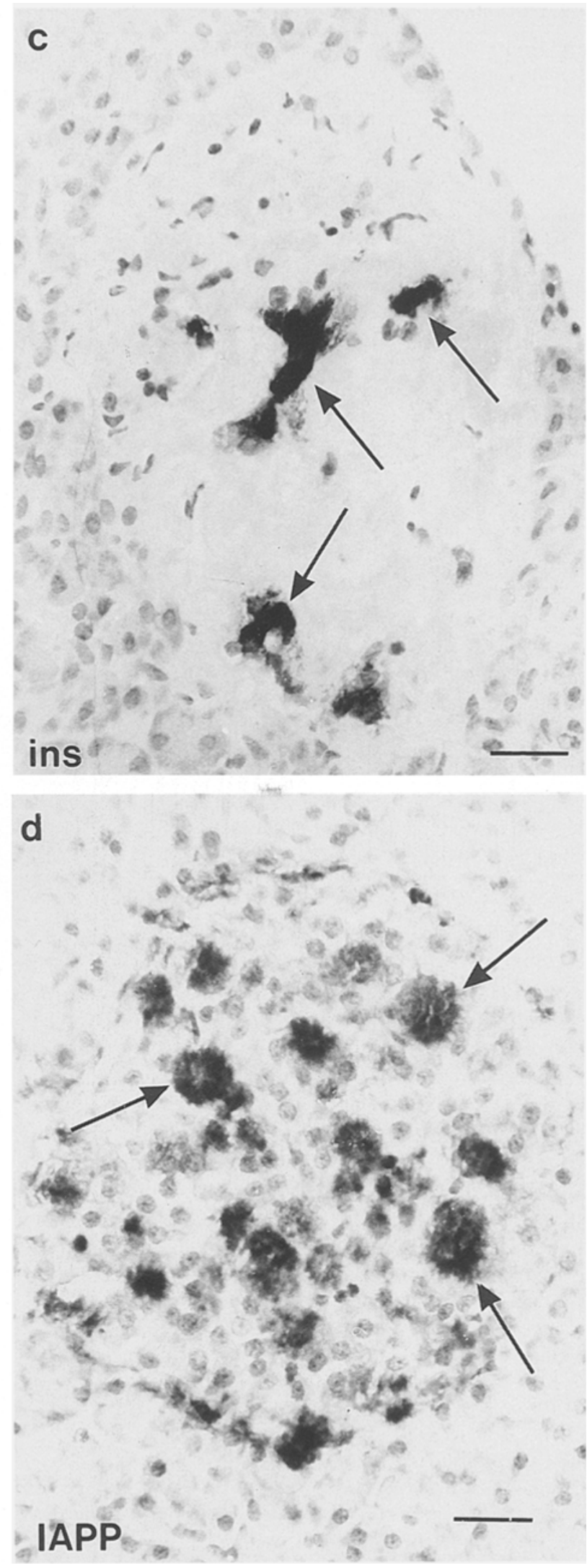

(arrows). An adjacent section through the same islet (b) shows large deposits of amyloid immunoreactive for IAPP. (d) Islet from a normoglycaemic hyperinsulinaemic monkey (monkey J) showing small amyloid deposits immunoreactive for IAPP (arrows). Scale bar $=50 \mu \mathrm{m}$ 

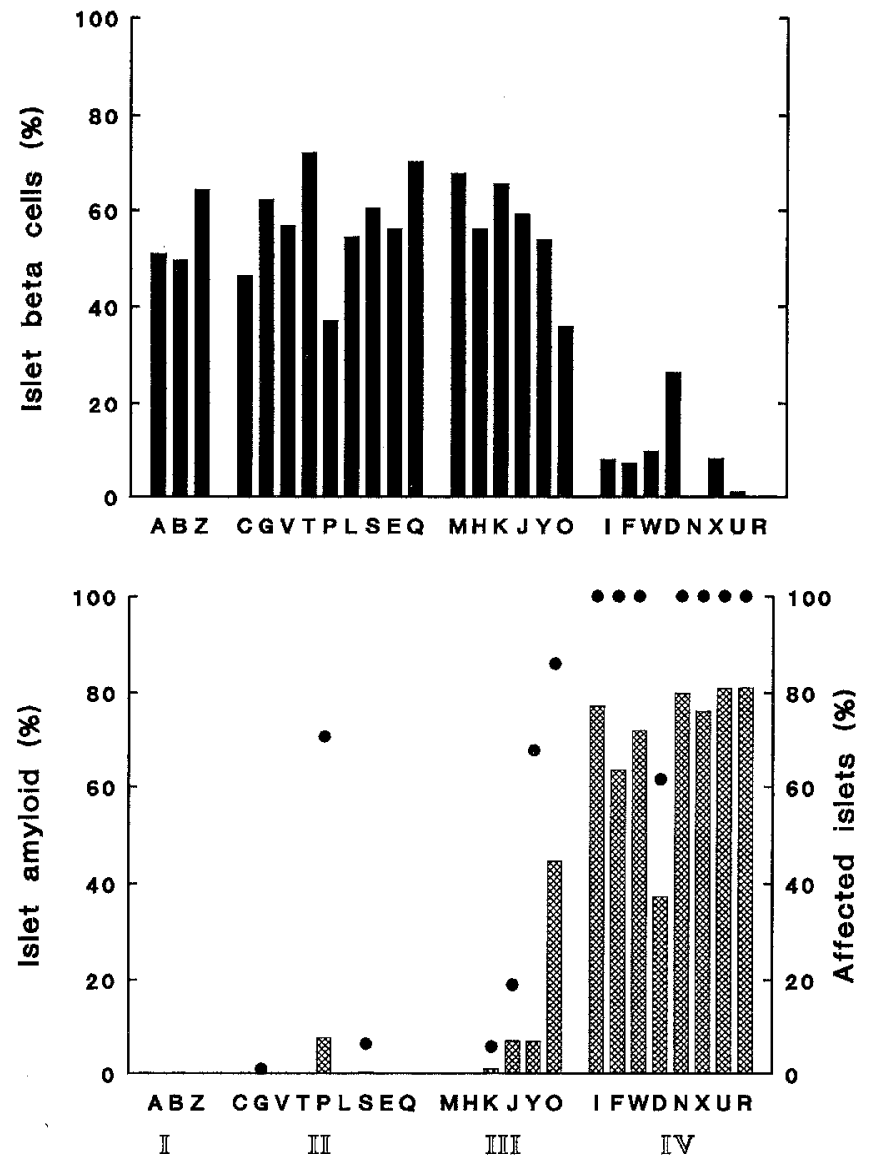

Fig.2. Proportion of islet beta-cells ( $\boldsymbol{\square}$ ) (top) and islet amyloid deposits (国) with proportion of islets affected (-) (bottom). Each animal is indicated by a single lettercode and assigned to one of four groups according to the physiological status at time of death. $\mathrm{I}=$ lean, normoglycaemic, normoinsulinaemic monkeys, less than 10 years old $(n=3)$. II = lean and obese, normoglycaemic, normoinsulinaemic monkeys, more than 10 years old $(n=9)$. III = normoglycaemic, hyperinsulinaemic monkeys $(n=6)$. IV = diabetic monkeys $(n=8)$. The proportion of islet beta cells is not different in groups I, II and III but markedly reduced in group IV. All diabetic animals have large amyloid deposits and every islet was affected in seven of eight animals

groups I and II were considered as one population for group analysis since they had been separated only on the basis of age. Correlations were tested by use of Spearman Rank and group differences determined by non-parametric analyses of variance tests (Van der Waerden 3 sample test). Probability values are given with $p<0.05$ considered to be significant.

\section{Results}

Pancreatic tissue from these monkeys was obtained immediately after death at necropsy. The specimens showed little evidence of autolysis and exhibited strong immunoreactivity for islet peptides (Fig.1a). All areas showing birefringence in polarised light following Congo red staining were immunoreactive for IAPP (Fig. 1 b). In this study more than 5000 islets were examined in pancreatic specimens from 26 Macacamulatta monkeys. All islets in a tissue section were included in the analysis. Islets were irregular in shape and 170 (59-430) (median and range) islets were examined per animal. There were no statistical differences

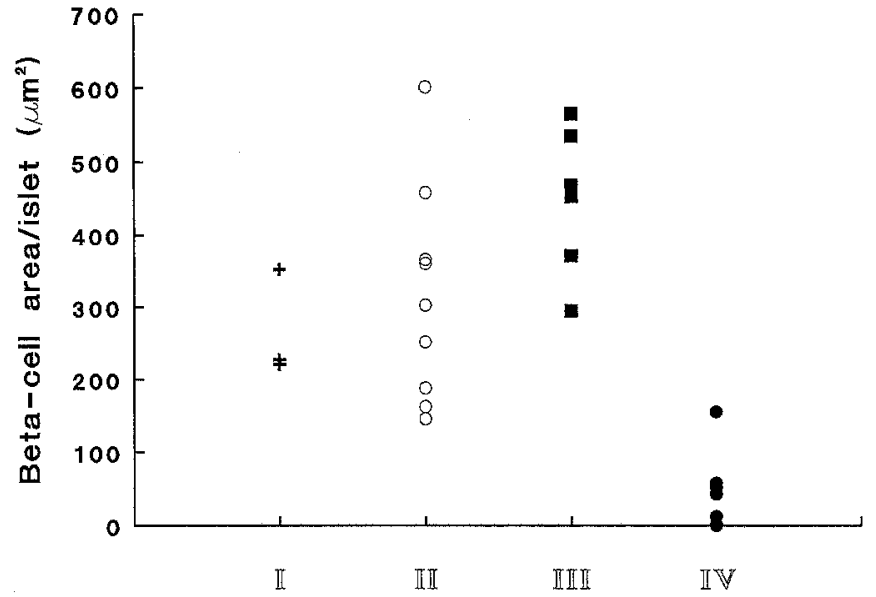

Fig.3. Beta-cell area per islet. $\mathrm{I}=$ lean, normoglycaemic, normoinsulinaemic monkeys, less than 10 years old $(n=3)$. II = lean and obese, normoglycaemic, normoinsulinaemic monkeys, more than 10 years old $(n=9)$. III = normoglycaemic, hyperinsulinaemic monkeys $(n=6)$. IV $=$ diabetic monkeys $(n=8)$. There is a significant increase in beta-cell area per islet in group III compared to group I and II $(p<0.05)$. The reduction in beta-cell area per islet in group IV is highly significant compared to group I and II $(p<0.0001)$ and group III $(p<0.0001)$. These data suggest that a reduction to a critical amount of beta-cell mass is associated with diabetes

in data calculated from measurements made on specimens from the body and specimens from the tail regions of the pancreas in any single animal. Therefore the data from the two regions were combined for each monkey.

Beta-cell area. Insulin immunoreactive cells were present throughout the islets in non-diabetic animals (Fig.1 a) and located as isolated cells or in small groups in amyloid deposits (Fig. 1c). B\% for each monkey in groups I-IV is depicted in Figure 2. The mean beta-cell area per islet was increased in group III $(p<0.05)$ and much reduced in diabetic monkeys $(p<0.0001)$ compared to animals from groups I and II (Table 1 and Fig. 3).

Islet amyloid. Islet amyloid was immunoreactive for IAPP. Central areas of the large deposits in some diabetic animals showed less IAPP immunoreactivity and contained extensive calcification. Amyloid deposits were found in all of the eight diabetic monkeys (group IV) (Fig.1 b) but were absent in the three young non-diabetic animals (group I). In groups II and III amyloid was present in three of nine and four of six animals, respectively. Large amounts of amyloid were present in each islet examined in seven of the diabetic animals, occupying more than $63 \%$ of islet space (Fig.2). Islet amyloidosis was less severe in one diabetic animal (monkey D) in which $62 \%$ of islets were affected. Amyloid deposits in normoglycaemic animals occupied less islet space and fewer islets were affected compared to animals of the diabetic group (Fig. 2). These smaller deposits either appeared circular in cross section scattered throughout the islet or were adjacent to islet capillaries (Fig. 1d)

Islet size. Islet size, expressed as the geometric mean of islet areas, varied in different groups. Islet size was in- 


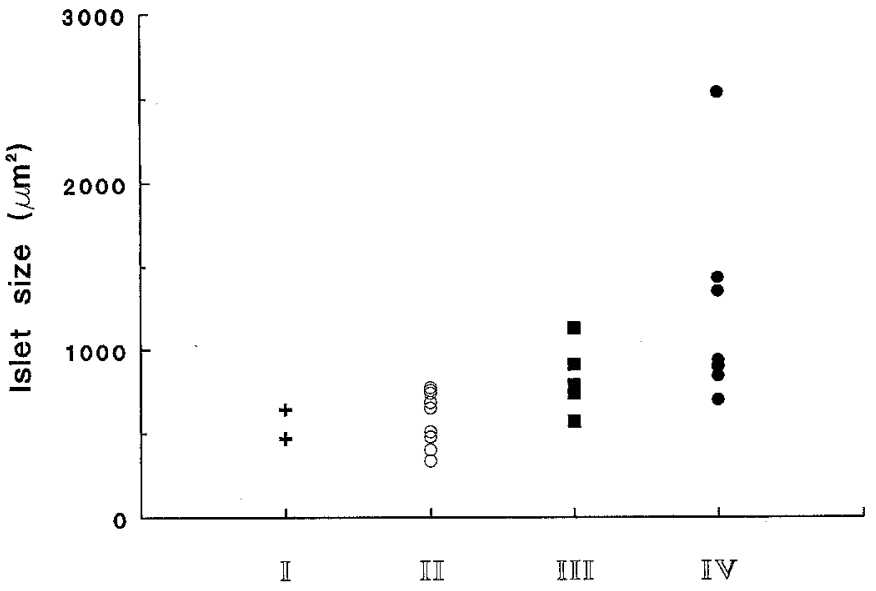

Fig.4. Islet size. $I=$ lean, normoglycaemic, normoinsulinaemic monkeys, less than 10 years old $(n=3)$. II = lean and obese, normoglycaemic, normoinsulinaemic monkeys, more than 10 years old $(n=9)$. III $=$ normoglycaemic, hyperinsulinaemic monkeys $(n=6)$. IV $=$ diabetic monkeys $(n=8)$. Islet size is significantly larger in group III $(p<0.01)$ and Group IV $(p<0.0001)$ compared to groups I and II

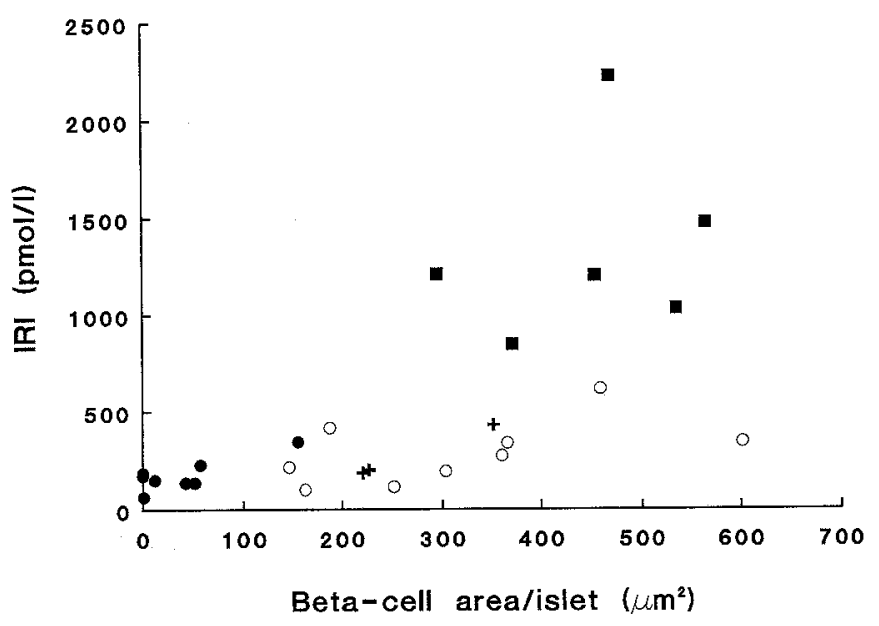

Fig.5. Relationship between fasting plasma immunoreactive insulin (IRI) levels and beta-cell area per islet. Each symbol represents a different group. Group I $(+)=$ lean, normoglycaemic, normoinsulinaemic monkeys, less than 10 years old. Group II (o) = lean and obese, normoglycaemic, normoinsulinaemic monkeys, more than 10 years old. Group III ( $\mathbf{a})=$ normoglycaemic, hyperinsulinaemic monkeys. Group IV (•) = diabetic monkeys. A significant correlation $(r=0.76, p<0.001)$ exists between physiological and morphological data

creased in groups III $(p<0.01)$ and IV $(p<0.0001)$ compared to groups I and II. (Table 2 and Fig. 4).

Islet area proportion. ISL \% was between $0.9-5.5 \%$ in animals of groups I and II. This proportion was significantly increased in animals of groups III $(p<0.05)$ and IV $(p<0.0001)$ compared to groups I and II such that the islet area formed up to $27 \%$ of the tissue area in diabetic animals (Table 2).

Relationships of morphological and physiological parameters. Elevated plasma IRI was associated with an increase in the beta-cell population of the islets $(n=26$; $r=0.77, p<0.001$ ) (Fig.5). This correlation also existed
Table 2. Morphometric data

\begin{tabular}{|c|c|c|c|c|c|}
\hline Group & Monkey & $\begin{array}{l}\text { Beta-cell } \\
\text { area/islet } \\
\left(\mu \mathrm{m}^{2}\right)\end{array}$ & $\begin{array}{l}\text { Amyloid } \\
\text { area/islet } \\
\left(\mu \mathrm{m}^{2}\right)\end{array}$ & $\begin{array}{l}\text { Islet size } \\
\left(\mu \mathrm{m}^{2}\right)\end{array}$ & $\begin{array}{l}\text { Islet area } \\
\text { proportion } \\
(\%)\end{array}$ \\
\hline I & $\begin{array}{l}\text { A } \\
B \\
Z\end{array}$ & $\begin{array}{l}227.0 \\
221.0 \\
352.2\end{array}$ & $\begin{array}{l}0.0 \\
0.0 \\
0.0\end{array}$ & $\begin{array}{l}467.5 \\
471.2 \\
642.7\end{array}$ & $\begin{array}{l}2.3 \\
1.5 \\
2.6\end{array}$ \\
\hline II & $\begin{array}{l}C \\
G \\
\text { V } \\
T \\
P \\
\text { L } \\
S \\
\text { E } \\
Q\end{array}$ & $\begin{array}{l}145.9 \\
303.1 \\
251.8 \\
601.7 \\
162.5 \\
366.2 \\
360.7 \\
188.0 \\
458.8\end{array}$ & $\begin{array}{r}0.0 \\
0.3 \\
0.0 \\
0.0 \\
18.9 \\
0.0 \\
0.4 \\
0.0 \\
0.0\end{array}$ & $\begin{array}{l}402.3 \\
509.8 \\
479.4 \\
772.5 \\
651.0 \\
755.5 \\
739.2 \\
335.9 \\
684.1\end{array}$ & $\begin{array}{l}1.7 \\
2.4 \\
1.0 \\
3.3 \\
3.2 \\
4.3 \\
2.8 \\
0.9 \\
5.5\end{array}$ \\
\hline III & $\begin{array}{l}\mathrm{M} \\
\mathrm{H} \\
\mathrm{K} \\
\mathrm{J} \\
\mathrm{Y} \\
\mathrm{O}\end{array}$ & $\begin{array}{l}535.5 \\
453.9 \\
565.6 \\
469.0 \\
295.3 \\
371.7\end{array}$ & $\begin{array}{r}0.0 \\
0.0 \\
0.4 \\
0.9 \\
9.0 \\
112.6\end{array}$ & $\begin{array}{r}911.0 \\
788.4 \\
1129.5 \\
739.4 \\
572.8 \\
762.1\end{array}$ & $\begin{array}{l}3.7 \\
3.4 \\
5.6 \\
5.4 \\
2.6 \\
6.2\end{array}$ \\
\hline IV & $\begin{array}{l}\mathrm{I} \\
\mathrm{F} \\
\mathrm{W} \\
\mathrm{D} \\
\mathrm{N} \\
\mathrm{X} \\
\mathrm{U} \\
\mathrm{R}\end{array}$ & $\begin{array}{r}43.0 \\
52.3 \\
57.8 \\
155.3 \\
0.4 \\
12.4 \\
1.0 \\
0.3\end{array}$ & $\begin{array}{r}2253.8 \\
889.3 \\
616.0 \\
23.3 \\
1179.9 \\
754.0 \\
272.0 \\
620.3\end{array}$ & $\begin{array}{r}2540.3 \\
1352.1 \\
937.4 \\
842.7 \\
1432.5 \\
895.6 \\
904.1 \\
699.7\end{array}$ & $\begin{array}{r}13.0 \\
5.9 \\
7.5 \\
3.0 \\
16.8 \\
10.2 \\
27.3 \\
16.2\end{array}$ \\
\hline
\end{tabular}

$\mathrm{I}=$ lean, normoglycaemic, normoinsulinaemic monkeys, less than 10 years old $(n=3) . \mathrm{II}=$ lean and obese, normoglycaemic, normoinsulinaemic monkeys, more than 10 years old $(n=9)$. III $=$ normoglycaemic, hyperinsulinaemic monkeys (fasting immunoreactive insulin (IRI) $>700 \mathrm{pmol} / \mathrm{l})(n=6)$. Group IV = diabetic monkeys (fasting plasma glucose $(\mathrm{FPG})>7.8 \mathrm{mmol} / \mathrm{l})(n=8)$

within the normoglycaemic animals (Groups I, II and III) $(n=18 ; r=0.68, p<0.002)$. Similarly, there was a strong correlation between the amount of islet amyloid (AM\%) and FPG $(r=0.83, p<0.001)$ but there was no relationship between the degree of islet amyloidosis and age, body weight, body fat proportion or IRI.

\section{Discussion}

There is a high incidence of diabetes in spontaneously obese Macaca mulatta monkeys. Each animal in our crosssectional study had been assigned to a phase in the progression of the disease on the basis of results of physiological tests. Longitudinal studies showed that the diabetic animals in Group IV had passed through successive phases of obesity and hyperinsulinaemia before the onset of hyperglycaemia [18]. These monkeys form a very appropriate animal model for the study of the aetiology and pathophysiology of the disease which is related to obesity as is the case for many patients with Type 2 diabetes. This is unlike the disease process in Macaca nigra; these animals do not develop obesity and the first sign of the disease process is impaired insulin secretion [20]. Howard et al. [21] found a reduction in beta-cell numbers and islet amyloid deposition in this unique form of primate diabetes. 
The endocrine cell population of islets in the body and tail regions of the non-diabetic Macaca mulatta pancreas in which insulin-containing beta cells occupy up to $72 \%$ of the islet space is similar to that of man [2]. The remainder of the islet comprises cells containing glucagon, pancreatic polypeptide, somatostatin, capillaries and, in some normal animals, small amyloid deposits. The body and tail regions of the pancreas were selected for analysis since cellular composition of the islets in these regions is more homogeneous than that of islets in the pancreatic head [23]. Islet amyloid is restricted to those islets derived from the dorsal pancreatic primordium in man [24]. The earliest phases in the aetiology of diabetes in Macaca mulatta has been considered from physiological measurements to be primarily related to the spontaneous development of obesity and insulin resistance [17]. However, the dramatic reduction in the islet beta-cell population found in diabetic animals suggests that the disease process, at its latest stages, is also characterized by a major deficiency in islet beta cells. Furthermore, fasting plasma insulin levels in these animals were closely related to the beta-cell population in the islets. It is interesting to note that the monkey with the highest fasting IRI in the diabetic group (monkey D) had the highest beta-cell area per islet and the least severe amyloidosis. Previous longitudinal physioiogical studies on this monkey showed that fasting plasma IRI levels had been falling from the time of onset of diabetes (B.C.Hansen, unpublished data). Although diabetic animals had a highly significant reduction in beta-cell population, the low fasting insulin levels were not different from those found in animals of groups I and II. This suggests that the low number of residual insulin-producing cells in islets of the diabetic animals must be hyperactive. Similar high levels of synthesis and release have been found in a streptozotocin (STZ)-induced model of diabetes in baboons with a $42 \%$ reduction in beta-cell mass [25]. However, there is no clearly defined minimum beta-cell mass associated with hyperglycaemia. Previous morphometric studies in Type 2 diabetes in man have shown no change [23] or $25 \%-40 \%$ reduction in beta-cell population [2,26] whereas a more severe reduction ( $>50 \%$ in beta-cell area per islet) was found in the present study.

Islet amyloidosis appears to precede the onset of overt diabetes in spontaneously diabetic Macaca mulatta as in Macaca nigra $[19,21]$ and spontaneously diabetic cats [27]. Small scattered amyloid deposits were found in pancreatic islets of obese and hyperinsulinaemic normoglycaemic animals but fewer islets were affected in these monkeys than in the diabetic animals. The small amyloid deposits were not associated with a significant reduction in beta-cell area and it is unlikely that the observed amount of amyloid would interfere physically with insulin secretion. The process of polymerization of amyloid peptides is progressive and once started the mechanism is continuous [28]. Association of amyloidosis and progression to diabetes is suggested from the data of one hyperinsulinaemic, normoglycaemic animal (monkey O); the moderately sized amyloid deposits were associated with a higher fasting plasma glucose level $(6.6 \mathrm{mmol} / \mathrm{l})$ and a lower plasma insulin level $(847 \mathrm{pmol} / 1)$ than that found in the other hyperinsulinaemic animals. The correlation be- tween the percentage of the islet occupied by amyloid and reduction of beta-cell area implicates amyloidosis in destruction of insulin-producing cells. A dramatic reduction in beta cells and little change in glucagon and somatostatin cells has been observed in the large islets studied in Macaca nigra [21].

Amyloid in pancreatic islets in man had long been thought to be a feature of aging but we found no relationship between the amount of amyloid and age. Two very old monkeys in group II (monkeys P and Q) remained normoglycaemic although one of them had small amyloid deposits indicating that the disease process, as in man, is very heterogeneous.

The increased islet size found in hyperinsulinaemic animals may represent either hypertrophy of beta cells or an increase in the number of beta cells in these islets. Islet size is increased in adult rats by infusion with glucose [29] and in genetically obese rats [30] and mice [31]. The possibility that animais with predetermined factors for the onset of diabetes have larger islets cannot be excluded. However, increased islet size associated with amyloidosis has been reported in Type 2 diabetic patients [32] and Macaca nigra [21], possibly related to progressive deposition of extracellular amyloid deposits.

Care should be taken about interpretation and measurement of islet size; separate areas may represent transection of the same islet at different positions due to the irregular shape of primate islets; similarly, single beta cells or small groups of beta cells may represent the outer border of larger islets. The irregularity of islet shape preciuded use of the Weibel transform for conversion of data to volume density [33]. Equally, calculation of islet volume from measured diameters is inappropriate with irregular shaped primate islets [34].

In the diabetic group, a relatively larger proportion of the pancreatic tissue was occupied by islets (up to $27 \%$ of tissue area). Although increased islet size would contribute to this phenomenon it is unlikely to be the only factor. Severe intralobular lipomatosis, pancreatitis or fibrosis of exocrine tissue, as has been observed in Type 2 diabetes [35], was not found in this study. Thus severe islet amyloidosis is not only associated with endocrine dysfunction but also with a dramatic reduction in exocrine proportion. As interlobular fat depositions were present in some animals but, by definition, not included in the tissue area in this study, calculations of islet and exocrine volume using pancreatic weight were unreliable. It has been shown that diminished exocrine secretory products and reduced exocrine volume are recognized features of Type 1 (insulindependent) diabetes and, to a lesser degree, Type 2 diabetes in man $[36,37]$. The requirement of a high intrapancreatic insulin level for maintenance of exocrine function has been proposed [38].

The important question that remains is whether islet amyloid is merely a secondary feature of beta-cell dysfunction or whether its deposition contributes to the development of the diabetic syndrome. Amyloid deposits may present a physical barrier in the islet and cause impaired beta-cell function, or may be part of a process of beta-cell deterioration. The massive accumulations of amyloid associated with beta-cell loss are likely to contribute to the in- 
creased severity of the disease in Macaca mulatta. Similar progressive islet amyloidosis in man has been associated with the eventual need for insulin therapy [4]. In this animal model an extensive amount of islet amyloid appears to be a sensitive pathological indicator for diabetes.

Acknowledgements. We are grateful to the British Diabetic Association (AC), the NIH R01-AG10612 (BCH), University of Oxford Medical Research Fund and British Council (EJPdeK) for support for these studies. We thank Ms J.Lloyd and Ms T. Alexander for technical assistance, Ms I. Stratton for advice on statistics and Dr. J.F. Morris and Dr. R. C. Turner for helpful discussions.

\section{References}

1. Bell ET (1952) Hybridization of the islets of Langerhans in diabetes mellitus. Diabetes 1:341-344

2. Clatk A, Wells CA, Buley ID et al. (1988) Islet amyloid, increased A-cells, reduced B-cells and exocrine fibrosis: quantitative changes in the pancreas in Type 2 diabetes. Diabetes Res 9: $151-160$

3. Maclean N, Oglivie RF (1955) Quantitative estimation of the pancreas islet tissue in diabetic subjects. Diabetes 4: 367-376

4. Clark A, Lewis CE, Willis AC, Cooper GJS, Morris JF, Reid KBM (1987) Islet amyloid formed from diabetes-associated peptide may be pathogenic in type 2 diabetes. Lancet II: 231-234

5. Schneider HM, Storkel S, Will W (1980) Das amyloid der Langerhansschen inseln und seine beziehung zum diabetes mellitus. Dtsch Med Wschr 105: 1143-1147

6. Westermark P, Wernstedt C, Wilander E, Hayden DW, O'Brien TD, Johnson KH (1987) Amyloid fibrils in human insulinoma and islets of Langerhans of the diabetic cat are derived from a neuropeptide-like protein also present in normal islet cells. Proc Natl Acad Sci USA 84:3881-3885

7. Cooper GJS, Leighton B, Dimitriadis GD et al. (1988) Amylin found in amyloid deposits in human type 2 diabetes mellitus may be a hormone that regulates glycogen metabolism in skeletal muscle. Proc Natl Acad Sci USA 85: 7763-7766

8. Lukinius A, Wilander E, Westermark GT, Engström U, Westermark P (1989) Co-localisation of islet amyloid polypeptide and insulin in the B-cell secretory granules of the human pancreatic islets. Diabetologia 32: 240-244

9. Clark A, Edwards CA, Ostle LR et al. (1989) Localisation of islet amyloid peptide in lipofuscin bodies and secretory granules of human B-cells and in islets of type 2 diabetic subjects. Cell Tissue Res 257: 179-185

10. Kanatsuka A, Makino H, Ohsawa $H$ et al. (1989) Secretion of islet amyloid polypeptide in response to glucose. FEBS Lett 259: 199-201

11. Kahn SE, D'Alessio DA, Schwartz MW et al. (1990) Evidence of cosecretion of islet amyloid polypeptide and insulin by $B$ cells. Diabetes 40: 305-309

12. Inoue K, Hisatomi A, Umeda F, Nawata H (1990) Amylin release from perfused rat pancreas in response to glucose and arginine. Diabetes Res Clin Pract 10: 189-192

13. Steiner DF, Ohagi S, Nagamatou S, Bell GI, Nishi M (1991) Is islet amyloid polypeptide a significant factor in pathogenesis or pathophysiology of diabetes? Diabetes 40: 305-309

14. Johnson KH, O'Brien TD, Betsholtz C, Westermark P (1989) Islet amyloid, islet amyloid polypeptide and diabetes mellitus. $\mathrm{N}$ Engl J Med 321: 513-518

15. Jordan K, Murtaugh MP, O'Brien TD, Westermark P, Betzholtz C, Johnson KH (1990) Canine IAPP CDNA sequence provides important clues regarding diabetogenesis and amyloidogenesis in type 2 diabetes. Biochem Biophys Res Comm 169: 502-508

16. Ohagi S, Nishi M, Bell GI, Ensinck JW, Steiner DF (1991) Sequences of islet amyloid polypeptide precursors of an old world monkey, the pig-tailed macaque (Macaca nemestrina) and the $\operatorname{dog}$ (Canis familiaris). Diabetologia 34: 555-558
17. Hansen BC (1987) Prospective study of the development of diabetes in spontaneously obese monkeys. In: Berry EM, Blondheim SH, Eliahou HE, Shafrir $\mathrm{E}$ (eds) Recent advances in obesity research, John Libbey, London, pp 33-41

18. Hansen BC, Bodkin NL (1986) Heterogeneity of insulin responses: phases leading to type 2 (non-insulin-dependent) diabetes mellitus in the rhesus monkey. Diabetologia 29:713-719

19. Howard CF (1974) Diabetes in Macaca nigra: metabolic and histologic changes. Diabetologia 10:671-677

20. Howard CF (1986) Longitudinal studies on the development of diabetes in individual Macaca nigra. Diabetologia 29:301-306

21. Howard CF (1986) Changes in islet cell composition during development of diabetes in Macaca nigra. Diabetes 35:165-171

22. Orci L (1982) Macro and micro domains in the endocrine pancreas. Diabetes 31: 538-565

23. Rahier J, Goebbels RM, Henquin JC (1983) Cellular composition of the human diabetic pancreas. Diabetologia 24:366-371

24. Clark A, Holman RR, Matthews DR, Hockaday TDR, Turner RC (1984) Non-uniform distribution of islet amyloid in the pancreas of 'maturity-onset' diabetic patients. Diabetologia 27: $527-$ 528

25. McCulloch DK, Koerker DJ, Kahn SE, Bonner-Weir S, Palmer JP (1991) Correlations of in vivo B-cell function tests with B-cell mass and pancreatic insulin content in streptozocin-administered baboons. Diabetes 40: 673-679

26. Saito K, Yaginuma N, Takahashi T (1979) Differential volumetry of A, B and D cells in the pancreatic islets of diabetic and nondiabetic subjects. Tohoku J Exp Med 129: 273-283

27. Johnson KH, O'Brien TD, Jordan K, Westermark P (1989) Impaired glucose tolerance is associated with increased islet amyloid polypeptide (IAPP) immunoreactivity in pancreatic betacells. Am J Pathol 135: 245-250

28. Pepys MB (1988) Amyloidosis: some recent developments. Quart J Med 252: 283-298

29. Bonner-Weir S, Deery D, Leahy JL, Weir GC (1989) Compensatory growth of pancreatic B-cells in adult rats after short-term glucose infusions. Diabetes 38: 49-53

30. Petkov P, Marquie G, Donev S, Dahmani Y, Duhault J (1985) Morphology of the endocrine pancreas in the diabetic sand rat (Psammomys obesus). Cell Molec Biol 316: 61-74

31. Starich GH, Zafirora M, Jablenska R, Petkov P, Lardinois CL (1991) A morphological and immunohistochemical investigation of endocrine pancreata from obese $o b+/ o b+$ mice. Acta Histochem 90: 93-101

32. Westermark P, Wilander E (1970) The influence of amyloid deposits on the islet volume in maturity onset diabetes mellitus. Diabetologia 15: 417-421

33. Weibel ER (1963) Principles and methods for the morphometric studies of the lung and other organs. Lab Invest 12: 131-155

34. Jones CW, Reynolds WA, Hogansen GE (1980) Streptozotocin diabetes in the monkey. Plasma levels of glucose, insulin, glucagon and somatostatin with corresponding morphometric analysis of islet endocrine cells. Diabetes 29: 536-546

35. Kloppel G (1984) Islet histopathology in diabetes mellitus In: Kloppel G, Heitz PU (eds) Pancreatic pathology. Churchill Livingstone, Edinburgh London Melbourne New York, pp 154-185

36. Fonseca V, Berger LA, Beckett AG, Dandona P (1985) Size of the pancreas in diabetes mellitus: a study based on ultrasound. $\mathrm{Br}$ Med J 291: 1240-1241

37. Dandona P, Freedman DB, Foo Y et al. (1984) Exocrine pancreatic function in diabetes mellitus. J Clin Pathol 37: 302-306

38. Korc M, Owerbach D, Quinto C, Ruttter WJ (1981) Pancreatic islet acinar cell interaction: amylase messenger RNA levels are determined by insulin. Science 213: 351-353

Received: 12 October 1992

and revised form: 7 December 1992

Dr. E.J.P. de Koning, Diabetes Research Laboratories

Radcliffe Infirmary, Woodstock Road

Oxford OX2 $6 \mathrm{HE}$, UK 